\title{
Peningkatan Hasil Belajar Speaking Menggunakan Teknik Know, What To Know, Learned and Monologue Text
}

\author{
Noerdjanah $^{1 *}$, Sugiono $^{2}$ \\ ${ }^{1,2}$ Poltekkes Kemenkes Surakarta Jurusan Fisioterapi \\ *Email: djanah1970@gmail.com
}

\begin{abstract}
Background: Speaking in English learning was crucial and essential. An increase in English language learning is not natural. The limitation of student speaking inhibits self-development in science, technology, and the arts. This study aims to determine the increase in the outcome of speaking learning using the technique of know, what to know, learned, and monologue text in physiotherapy students college. Methods: Quantitative experiment research without control group design. The amount of sample is 48 physiotherapy students in first grade. Instrumen to describe the result of the study consist of 40 questions. Students study using know what to know learned, and monologue text for two months. The date was analyzed using the paired t-test. Results: The result of the paired t-test shows that the P-value is 0,000. Based on the results, the technical influence testing technique of know, what to know, learned, and monologue text, there is an increase in the outcome of learning outcomes, from results pretest, posttest. This can be noted there are influences of the technique of know, what to know, learned, and monologue text in improving the outcome of learning physiotherapy students college of Poltekkes Kemenkes Surakarta. Conclusion: Recommendation and implication of the study, students are expected to be able to provide new knowledge about KWL techniques that are applied in understanding monologue texts and speaking practices so that students are easy to understand a text in English and spoken in speaking practice.
\end{abstract}

Keywords: learned and monologue text, learning outcome,speaking,technique of know, what to know

\section{PENDAHULUAN}

Fungsi pembelajaran bahasa Inggris merupakan perangkat pengembangan diri mahasiswa pada bidang ilmu pengetahuan, teknologi serta seni (Ratminingsih 2014). Kurikulum apapun yang ditentukan oleh pemerintah, guru diharapkan dapat melakukan pengembangan empat ketrampilan bahasa yang dipunyai siswa. Hal itu dinyatakan oleh Pranowo (2014) dimana apapun kurikulum yang digunakan dan apapun acuan teori yang dipakai, pembelajaran berbahasa berkaitan dengan empat ketrampilan yakni keterampilan mendengarkan, berbicara, membaca, dan menulis baik pada bidang bahasa ataupun sastra. Pembelajaran bahasa Inggris di Fisioterapi mencakup empat keterampilan bahasa yakni menyimak, membaca, berbicara dan menulis (Megawati, 2016).
Seluruh keterampilan tersebut didukung unsur-unsur bahasa lain, yakni: vocabulary, grammar dan pronunciation berdasarkan tema untuk alat meraih tujuan (Kusumayati, 2015).

Berdasarkan ke empat kterampilan berbahasa tersebut diatas, pembelajaran ketrampilan berbicara ternyata kurang bisa berjalan dengan mestinya. Mahasiswa belum cakap untuk melakukan komunikasi meskipun pembelajaran bahasa Inggris tersebut sederhana sekali. Dengan Visi dan Misi dari Fisioterapi diharapkan bahwa mahasiswa yang sudah menyelesaikan jenjang pendidikan Fisioterapi harus dapat melakukan penyampaian ide, pendapat, atautanggapan pada sebuah masalah pada pembelajaran bahasa Inggris. 
Setelah seluruh mahasiswa Fisioterapi belajar bahasa Inggris selama dua semester, mahasiswa harus mampu mempergunakan bahasa Inggris dalam melakukan komunikasi meskipun dalam bentuk sederhana (Megawati, 2016). Bahkan dalam pelajaran lainnya banyak literature yang menggunakan bahasa Inggris, hal itu menjadi motivasi mahasiswa untuk belajar bahasa Inggris. Salah satu usaha untuk menyelesaikan masalah tersebut, dosen bahasa Inggris di Fisioterapi berminat melaksanakan Penelitian Tindakan Kelas yang pada kesempatan ini dilaksanakan mahasiswa Fisioterapi, berjudul "Meningkatkan Hasil Belajar Speaking Melalui Teknik KWL (know, what to know, learned ) dan Texs Monolog" di Jurusan Fisioterapi.

Ketrampilan berbicara merupakan kemampuan mengeluarkan pendapat ataupun pikiran serta perasaan terhadap seseorang ataupun kelompok dengan lisan, baik face to face maupun jarak jauh. Sementara Haron et.al., (2012) menyatakan bahwa makna berbicara adalah kemampuan seseorang memproduksi kata-kata yang merepresentasikan opini, maksud atau perasaan untuk menumbuhkan interaksi kepada orang lain. Kohn et.al., (2017) dan Akkakoson, (2016) menekankan bahwa kesuksesan pembelajaran bahasa asing diukur pada kemampuan melakukan pembicaraan (conversation) dengan menggunakan bahasa asing tersebut. Rahmah dan Ray (2019) mengungkapkan berbicara adalah alat komunikasi secara alami diantara anggota masyarakat guna memberikan ungkapan pikiran dan sebagai suatu bentuk perilaku sosial. sementara, Lindawati (2018) mengungkapkan tujuan pembelajaran bahasa Inggris saat ini yaitu berbicara.
Purwanto (2017) mengungkapkan ketrampilan berbicara merupakan kecakapan dalam melakukan penyusunan kalimat sebab komunikasi terjadi lewat kalimat guna menampilkan perbedaan perilaku yang beragam dari masyarakat yang beragam pula.

Perihal yang bisa meningkatkan keterampilan berbicara mahasiswa dengan spontan, yakni melalui penggalian pengetahuan mahasiswa mengenai tema yang sedang diajarkan. Teknik KWL bisa dipergunakan sebagai alat untuk meraih tujuan itu. Metode KWL adalah kepanjangan dari know-want to knowlearned. Dengan demikian, teknik ini dikembangkan Ogle guna memberikan bantuan bagi guru menghidupkan latar belakang pengetahuan dan minat mahasiswa terhadap sebuah topik. Teknik KWL melibatkan tiga tahap dasar yang dapat menuntun mahasiswa memahami suatu wacana. Metode KWL diciptakan dengan dasar bahwa membaca bisa berhasil apabila diawali dengan kepemilikan skema atas isi dari bacaan. Tiga tahap dalam metode KWL tersebut memuat bermacam aktivitas yang dapat meningkatkan kecakapan membaca pemahaman siswa diantaranya curah pendapat, menetapkan kategori dan organisasi ide, melakukan penyusunan pertanyaan dengan spesifik, dan melakukan pengecekan beberapa hal yang ingin dipelajari atau diketahui mahasiswa dari suatu bacaan (Abidin, 2012). Lebih lanjut, Abidin (2012) menyatakan langkah-langkah teknik KWL ada tiga tahapan yakni: 1. Tahap Prabaca: a. Tahap Know (Apa yang saya ketahui). Langkah ini terdiri dari dua langkah yakni curah pendapat dan menghasilkan kategori ide. Curah pendapat dilaksanakan untuk melakukan penggalian bermacam 
pengetahuan yang sudah mahasiswa miliki mengenai topik bacaan. Untuk tahap pertama ini, guru memulai tahap tersebut dengan memberikan pengajuan pertanyaan misalnya, Apa yang kamu ketahui tentang...?. b. Tahap What I want to learn (W) (apa yang ingin saya ketahui). Pada langkah ini, guru memberikan penuntutan terhadap mahasiswa dalam melakukan penyusunan tujuan khusus dari membaca. Berdasarkan rasa ingin tahu, minat, dan ketidakjelasan, yang muncul saat tahap pertama ini, guru mengajak mahasiswa membuat bermacam pertanyaan yang jawabannya tersebut ingin diketahui mahasiswa. Guru memulai tahap tersebut dengan memberikan pertanyaan, misalnya apa yang ingin kamu ketahui tentang...?. 2. Tahap membaca: a. Tahap What I Have Learned (L) 4. Sesudah kegiatan membaca selesai, mahasiswa menuliskan seluruh hal yang sudah didapatnya dari aktivitas membaca berdasarkan pertanyaan yang diajukan pada langkah sebelumnya. 3. Tahap Pascabaca: a. Tahap tindak lanjut. Untuk langkah ini bermacam pertanyaan yang tidak bisa dijawab oleh mahasiswa, guru membahas bersama mahasiswa dalam diskusi kelas yang tersaji pada Tabel 1 .

Tabel 1. Metode KWL (Know-Want To Know-Learned)

\begin{tabular}{lll}
\hline \multicolumn{1}{c}{ K (Know) } & \multicolumn{1}{c}{ W (What to know) } & \multicolumn{2}{c}{ L (Learning) } \\
\hline & & Mahasiswa Membaca \\
Mengetahui tentang topic & Apa yang mereka pelajari & materi dan dosen \\
yang diberikan & tentang topic & yangali tentang apa \\
& & pelajari
\end{tabular}

Pada saat pembelajaran, dosen
memberi suatu topik, selanjutnya
diberikan pertanyaan oral terhadap
mahasiswa apa yang diketahui mengenai
topik yang diberikan oleh dosen. Seluruh
jawaban mahasiswa ditulis pada kolom K.
Selanjutnya pertanyaan yang diberikan
adalah apa yang ingin mahasiswa pelajari
mengenai topik dan seluruh jawaban
mahasiswa ditulis pada kolom W. Selanjutnya mahasiswa disuruh membaca materi storytelling pada hari tersebut. Selanjutnya dosen melakukan penggalian mengenai apa yang sudah mereka pelajari dan ditulis pada kolom $\mathrm{L}$.

Metode pembelajaran lewat metode KWL akan lebih efektif dan suasana belajar akan lebih menyenangkan jika dibarengi dengan storytelling berdasarkan ruang lingkup tema dan mahasiswa. Wright dan Backy (1984) menyatakan permainan bahasa dapat memberikan bantuan dan motivasi kepada mahasiswa dan melibatkan mahasiswa dalam berbicara serta bekerja. Permainan bahasa diyakini bisa menghasilkan situasi yang mana bahasa tersebut berarti dan berguna. Permainan bahasa yang bisa dipergunakan di sini antara lain word guessing, chaind words, role play, dan lain sebagainya.

Penelitian ini bertujuan menganalisis peningkatan hasil belajar speaking menggunakan teknik know, what to know, learned and monologue text pada mahasiswa Fisioterapi.

\section{METODE PENELITIAN}

Metode penelitian menggunakan desain quasi eksperimen. Desain ini tidak menggunakan kelompok kontrol, karena kelompok kontrol dalam quasi eksperimen tidak bisa memberikan fungsi secara 
penuh guna melakukan kontrol beberapa variabel luar yang berpengaruh terhadap kegiatan eksperimen.

Populasi pada riset ini yaitu mahasiswa fisioterapi tingkat I tahun 2018-2019, sebanyak 98 mahasiswa. Adapun sampel penelitian yang digunakan sebanyak 48 mahasiswa. Penentuan sampel dilaksanakan menggunakan metode random sampling. Alat dalam mengumpulkan data yang digunakan berupa soal test. Soal test yang digunakan untuk menggambarkan hasil penelitian terdiri dari 40 pertanyaan.

Variabel independen pada studi ini yaitu metode pembelajaran KWL dan teks Monolog. Metode KWL adalah metode pembelajaran dengan langkah mengetahui (know), keinginan (want) dan mempelajari (learn). Sedangkan variabel dependen pada studi ini yaitu hasil belajar kognitif speaking. Hasil pembelajaran yang dimaksud adalah pencapaian pengetahuan mahasiswa tentang pengetahuan mengenai speaking.

Analisis data dilakukan dengan membandingkan hasil pembelajaran kognitif speaking dengan metode know, what to know, and learned and text monolog. Pembelajaran siswa menggunakan know, what to know, learned dan text monolog selama 2 bulan. Data dianalisis dengan menggunakan paired t test.

Permintaan Ethical Clearance diajukan kepada Komisi Etik Penelitian Kesehatan (KEPK) Poltekes Surakarta sebelum melaksanakan penelitian. Persetujuan penelitian kepada mahasiswa diikutsertakan dalam soal test bentuk informed consent tertulis, sebelum mengerjakan soal. Sebelum memberi persetujuan, calon subjek penelitian diberi penjelasan mengenai tujuan dan manfaat penelitian.

\section{Hasil Uji Normalitas}

Sesuai dengan hasil uji normalitas Kolmogorov-Smirnov Z diketahui semua variable berdistribusi normal $\mathrm{p}>0.05$. Hasil uji normalitas dengan mempergunakan Kolmogorov Smirnov dihasilkan nilai asymp.sig lebih dari 0,05. sehingga data terdistribusi normal. Berikut hasil uji normalitas selengkapnya

Tabel 2. Hasil Uji Normalitas

\begin{tabular}{lccc}
\hline & N & KS_Z & Asymp. Sig. (2-tailed) \\
\hline KWl_Pretest & 48.00 & 0.61 & 0.85 \\
KWl_Post_Siklus2 & 48.00 & 0.61 & 0.86 \\
TM_Pretest & 48.00 & 0.65 & 0.80 \\
TM_Post_Siklus2 & 48.00 & 0.60 & 0.86 \\
\hline
\end{tabular}

\section{Hasil Uji Homogenitas}

Sebelum uji hipotesis data dianalisis dengan uji homogenitas. Peneliti menggunakan uji Levene test. Data yg dianalisis adalah perbandingan pre test dimana sebelum perkuliahan dimulai dengan setelah pembelajaran KWL dan teks monolog sebanyak 4 kali dalam waktu 2 bulan. Hasil dari uji homogenitas diperlihatkan pada tabel di bawah ini. 
Tabel 3. Hasil uji homogenitas

\begin{tabular}{lcccc}
\hline & $\begin{array}{c}\text { Levene } \\
\text { Statistic }\end{array}$ & df1 & df2 & Sig. \\
\hline Pretest & 0.101 & 1 & 94 & 0.751 \\
Post_Siklus2 & 0.171 & 1 & 94 & 0.681 \\
\hline \multicolumn{2}{c}{ Berdasarkan hasil uji homogenitas } & HASIL PENELITIAN & \\
$\begin{array}{l}\text { dengan levene test, diketahui nilai Sig. } \\
\text { lebih dari 0,05. Jadi dapat disimpulkan }\end{array}$ & $\begin{array}{l}\text { dikerdasarkan hai data statistik penelitian } \\
\text { sampel penelitian bisa dinyatakan } \\
\text { homogen. }\end{array}$
\end{tabular}

Tabel 4. Data Statistik Penelitian pembelajaran KWL

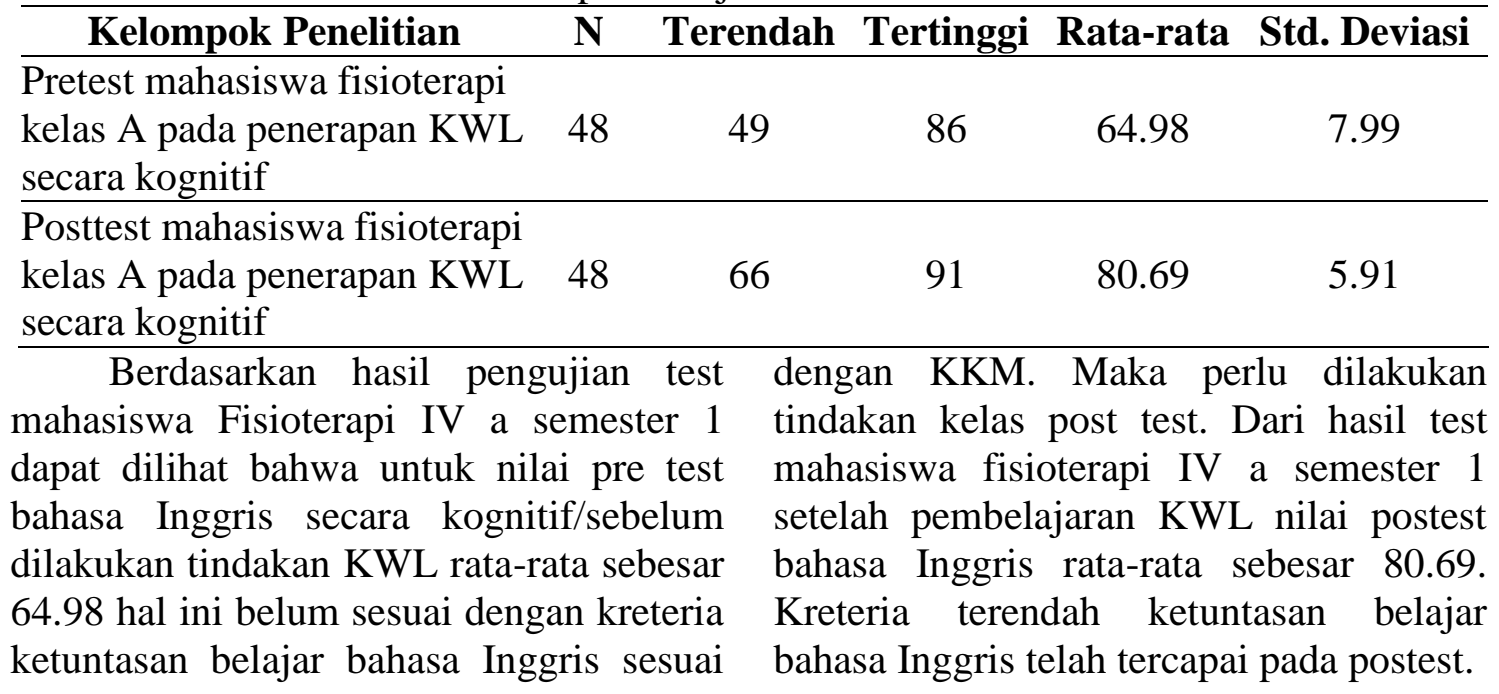

Tabel 5. Data Statistik Penelitian pembelajaran Teks Monolog

\begin{tabular}{|c|c|c|c|c|c|}
\hline Kelompok Penelitian & $\mathbf{N}$ & Terendah & Tertinggi & Rata-rata & $\begin{array}{c}\text { Std. } \\
\text { Deviasi }\end{array}$ \\
\hline $\begin{array}{l}\text { Pretest mahasiswa } \\
\text { fisioterapi kelas A pada } \\
\text { penerapan Teks Monolog } \\
\text { secara kognitif }\end{array}$ & 48 & 42 & 78 & 59.90 & 8.49 \\
\hline $\begin{array}{l}\text { Posttest mahasiswa } \\
\text { fisioterapi kelas A pada } \\
\text { penerapan Teks Monolog } \\
\text { secara kognitif }\end{array}$ & 48 & 72 & 96 & 84.17 & 5.63 \\
\hline $\begin{array}{l}\text { Berdasarkan hasil } \\
\text { mahasiswa fisioterapi IV } \\
\text { dapat dilihat bahwa untul } \\
\text { bahasa Inggris secara }\end{array}$ & $\begin{array}{l}\text { sujia } \\
\text { sem }\end{array}$ & $\begin{array}{ll}\text { test } & \text { dilak } \\
\text { er } 1 & \text { sebes } \\
\text { test } & \text { krete } \\
\text { lum } & \text { sesuc }\end{array}$ & $\begin{array}{l}\text { ukan tindak } \\
\text { sar } 59.90 \mathrm{~h} \\
\text { ria ketunta } \\
\text { ai dengan }\end{array}$ & $\begin{array}{l}\text { in teks mon } \\
\text { ini belum s } \\
\text { in belajar b } \\
\text { KKM. }\end{array}$ & $\begin{array}{l}\text { g rata-ra } \\
\text { uai denga } \\
\text { asa Inggr } \\
\text { ka per }\end{array}$ \\
\hline
\end{tabular}


dilakukan tindakan kelas berupa postest. Dari hasil postest mahasiswa fisioterapi IV a semester 1 dapat dilihat bahwa nilai postest hasil pembelajaran teks monolog bahasa Inggris rata-rata sebesar 84.17. Kriteria terendah ketuntasan belajar bahasa Inggris telah tercapai pada postest.

\section{Uji T}

Berdasarkan uji beda dengan Paired Samples Test, diketahui perbedaan hasil pre test dan post test teknik KWL pada tabel 6 berikut:

Tabel 6. Hasil uji beda

\begin{tabular}{llccc}
\hline & & Selisih rata-rata & t & Sig. (2-tailed) \\
\hline Pair 1 & KW1_Pretest - KWl_Posttest & -15.708 & -12.360 & 0.000 \\
Pair 2 & TM_Pretest - TM_Posttest & -24.271 & -17.957 & 0.000 \\
Pair 3 & KW1_Posttest - TM_Posttest & -3.479 & -3.236 & 0.002 \\
\hline
\end{tabular}

Berdasarkan hasil analisis dalam tabel di atas, peningkatan hasil belajar kognitif speaking metode KWL, diketahui dari selisih nilai rata-rata KWl_Pretest dengan post test. Selisih yang terjadi sebesar 15.708, dan hasil uji bedanya menunjukkan sig. kurang dari 0,05. Dari hasil tersebut bisa dinyatakan bahwa ada pengaruh signifikan metode KWL terhadap hasil belajar kognitif speaking.

Berdasarkan hasil analisis dalam tabel di atas, peningkatan hasil belajar kognitif speaking Teks Monolog, diketahui dari selisih nilai rata-rata TM_Pretest dengan post test. Selisih yang terjadi sebesar 24.271, dan hasil uji bedanya menunjukkan sig. kurang dari 0,05 . Dari hasil tersebut bisa dinyatakan ada pengaruh signifikan metode pembelajaran Teks Monolog terhadap hasil belajar kognitif speaking.

Berdasarkan hasil analisis dalam tabel di atas, peningkatan hasil belajar kognitif speaking antara metode KWL dengan metode Teks Monolog, diketahui dari selisih nilai rata-rata KWl_posttest dengan TM_posttest. Selisih yang terjadi sebesar 3.479, dan hasil uji bedanya menunjukkan sig. kurang dari 0,05. Dari hasil tersebut bisa dinyatakan metode pembelajaran Teks Monolog nilai hasil belajar kognitif speaking-nya lebih tinggi dibandingkan dengan metode pembelajaran KWL. Jadi dapat disimpulkan metode Teks Monolog lebih efektif.

\section{PEMBAHASAN}

Berdasarkan penelitian, terdapat pengaruh signifikan metode pembelajaran KWL terhadap hasil belajar kognitif speaking. Hal ini sejalan dengan temuan penelitian Santosa dan Asto (2015), bahwa KWL memberikan pengaruh terhadap pendekatan guru, persiapan dan proses pengiriman pelajaran, memberikan pengaruh positif terhadap motivasi dan partisipasi mahasiswa di kelas, berpengaruh positif terhadap hasil belajar, ingatan, penilaian diri dan sebagai petunjuk belajar di masa mendatang. Model pembelajaran KWL merupakan pembelajaran yang kooperatif dan menuntut adanya kerjasama antar mahasiswa dan saling bergantung pada struktur tugas, tujuan, serta hadiah. Mahasiswa tidak belajar akademik dan ketrampilan saja, namun juga diberikan pelatihan kerja sama pada kelompok dan mencapai tujuan pembelajaran bersama kelompoknya itu. Pada proses pembelajaran ini, mahasiswa dibagi dalam 
beberapa kelompok pada satu kelas yang bukan hanya sekedar kelompok, namun kelompok yang dapat melakukan kerjasama dalam belajar dan berhasil secara bersama-sama.

Berdasarkan analisis diketahui terdapat pengaruh yang signifikan metode pembelajaran Teks Monolog terhadap hasil belajar kognitif speaking. Hal ini sejalan dengan temuan penelitian Selvianti, Herpratiwi, \& Sukirlan (2013), bahwa teks monolog terbukti dapat meningkatkan kemampuan siswa. Metode tersebut dikolaborasikan dengan metode demontrasi. Kemampuan mahasiswa bermonolog yang meningkat dipersepsikan sebagai data produknya, diambil lewat produk berbicara yang muncul pada setiap siklus pembelajaran teks prosedur dengan mempergunakan metode demonstrasi. Indikator keberhasilan dari pelaksanaan tindakan tersebut jika $75 \%$ atau lebih mahasiswa meraih nilai minimal yaitu 70 .

Berdasarkan uji benda antara metode KWL dengan metode Teks Monolog, diketahui metode pembelajaran Teks Monolog menunjukkan nilai hasil belajar kognitif speaking-nya lebih tinggi dibandingkan dengan metode pembelajaran KWL. Penelitian ini merupakan awal, dimana belum pernah ada peneliti yang mengangkat penelitian teks monolog sebagai model penelitian. Selama ini teks monolog merupakan media guru dalam menempatkan materi pelajaran, misalnya teks monolog deskriptif, naratif, teks prosedur dan materi pelajaran teks atau wacana lainnya.

\section{KESIMPULAN DAN SARAN}

Sesuai dengan hasil penelitian bisa diambil kesimpulan bahwa metode pembelajaran terbukti mampu meningkatkan hasil belajar kognitif speaking mahasiswa. Metode pembelajaran teks monolog juga terbukti dapat meningkatkan hasil belajar kognitif speaking mahasiswa. Metode pembelajaran yang paling efektif dalam meningkatkan hasil belajar kognitif speaking mahasiswa, adalah metode teks monolog.

Sebagaimana simpulan diatas, maka ada baiknya, setiap pembelajaran dikembangkan metode-metode yang dapat meningkatkan hasil belajar kognitif speaking mahasiswa. Pengembangan metode pembelajaran ini merupakan upaya agar dalam pertemuan pembelajaran tidak terjadi kejenuhan sehingga kegiatan pembelajaran dapat berlangsun aktif. Hendaknya teks monolog dapat dikembangkan lagi sebagai referensi metode pembelajaran bahasa asing, khususnya dalam melatih ketrampilan berbicara di depan umum. Teks monolog merupakan metode dimana mahasiswa dapat mengungkapkan katakata melalui teks yang dituliskan dalam catatannya dan dalam bentuk monolog.

\section{DAFTAR RUJUKAN}

Abidin, Y. (2012). Pembelajaran Membaca Berbasis Pendidikan Karakter. Bandung: Refika Aditama.

Akkakoson, S. (2016). Speaking Anxiety in English Conversation Classrooms among Thai Students. Malaysian Journal of Learning and Instruction, 13(1), 63-82.

Stephen, K., \& McTaggart, R. (1988). The Action Research Planner: Action research and the critical analysis of pedagogy. Deakin University. 
Gage, H.L, \& Berliner, D.C. (1984). Educational Psychology. Chicago: Rand Mc Nally College Publishing

Haron, S.C., Ahmad, I.S., Mamat, A., and Ahmed, I.H. (2012). Using media to enhance Arabic Speaking Skills among Malay Learners. Journal of Education and Education and Practice ). Journal of Education and Practice. Vol.3 No.12: 100-110.

Kohn, K., \& Hoffstaedter, P. (2017). Learner agency and non-native speaker identity in pedagogical lingua franca conversations: Insights from intercultural telecollaboration in foreign language education. Computer Assisted Language Learning, 30(5), 351-367.

Kusumayati, L. D. (2015). Penggunaan Whole Brain Teaching (WBT) Untuk Meningkatkan Kemampuan Berbicara Mahasiswa. Widya Wacana: Jurnal Ilmiah, 9(1).

Larsen-Freeman, D. (2000). Techniques and Principles in Language Teaching. Oxford: Oxford University Press.

Lindawati, N. P., \& Sengkey, F. (2018). Peningkatan Keterampilan Berbicara Bahasa Inggris dengan Teknik Role Play pada Siswa kelas $\mathrm{X}$ SMA Dwijendra Denpasar. Jurnal Manajemen Pelayanan Hotel, 1(1), 1-8.

Megawati, F. (2016). Kesulitan mahasiswa dalam mencapai pembelajaran bahasa Inggris secara efektif. PEDAGOGIA: Jurnal pendidikan, 5(2), 147-156.

Nurgiyantoro, B. (2001). Penilaian dalam Pengajaran Bahasa dan Sastra. Yogyakarta: BPFE.

Octarina, D. (2001). Interactive activities as the way to improve EFL learners' speaking abilities. Practice. Vol.3 No.9: 82-87.

Pranowo. (2014). Teori Belajar Bahasa. Yokyakarta: Pustaka Pelajar.

Purwanto, H. S. J. (2017). Pengembangan Model Pembelajaran Berbicara Bahasa Jawa Berbasis Analisis Kesantunan di Sekolah Menengah Kejuruan. ADITYA-Pendidikan Bahasa dan Sastra Jawa, 11(1), 158-170.

Ratminingsih, N. M. (2014). Pengembangan model pembelajaran bahasa Inggris induktif berbasis lagu kreasi. Jurnal Ilmu Pendidikan, 20(1).

Richards, J.C. (2008). Teaching Listening and Speaking: From Theory to Practice. Cambridge: Cambridge Press University.

Rofi'udin, A., \& Zuhdi, D. (2001). Pendidikan Bahasa dan Sastra Indonesia di Kelas Tinggi. Malang: Universitas Malang.

Santoso, A. B., \& Asto B, I. (2015). Pengaruh Metode Pembelajaran KWL (Know, Want, Learn) Terhadap Hasil Belajar Siswa di 
SMK Negeri 2 Surabaya. Jurnal Pendidikan Teknik Elektro, 4(3).

Selvianti, S., Herpratiwi, H., \& Sukirlan, M. (2013). Peningkatan Kemampuan Siswa dalam Monolog Prosedur melalui Metode Demonstrasi. Jurnal Teknologi Informasi Komunikasi Pendidikan $($ Old $), 1(6)$.

Wright and Backy. (1984). Language art: Content and strategies. London: Longman. 